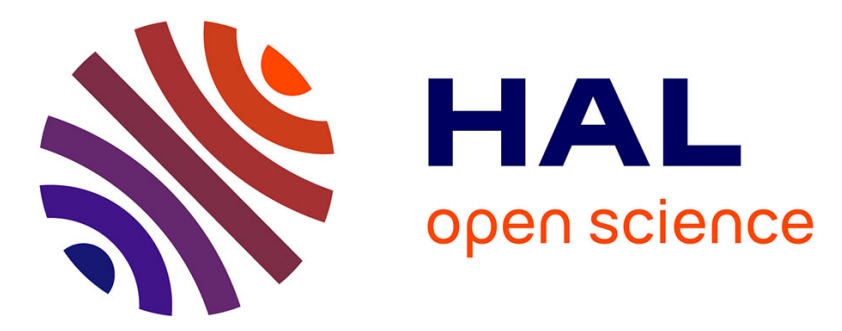

\title{
Investigations on the migration behaviour of silicone moulds in contact with different foodstuffs
}

\author{
Ruediger Helling, Katja Kutschbach, Thomas Joachim Simat
}

\section{To cite this version:}

Ruediger Helling, Katja Kutschbach, Thomas Joachim Simat. Investigations on the migration behaviour of silicone moulds in contact with different foodstuffs. Food Additives and Contaminants, 2010, 27 (03), pp.396-405. 10.1080/19440040903341869 . hal-00573083

\section{HAL Id: hal-00573083 \\ https://hal.science/hal-00573083}

Submitted on 3 Mar 2011

HAL is a multi-disciplinary open access archive for the deposit and dissemination of scientific research documents, whether they are published or not. The documents may come from teaching and research institutions in France or abroad, or from public or private research centers.
L'archive ouverte pluridisciplinaire HAL, est destinée au dépôt et à la diffusion de documents scientifiques de niveau recherche, publiés ou non, émanant des établissements d'enseignement et de recherche français ou étrangers, des laboratoires publics ou privés. 


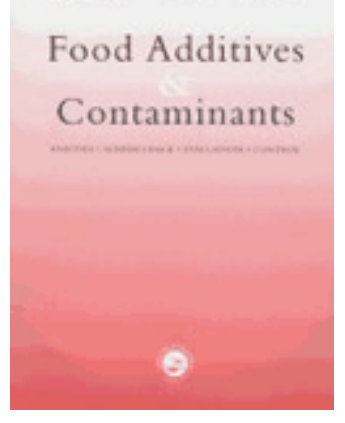

\section{Investigations on the migration behaviour of silicone moulds in contact with different foodstuffs}

\begin{tabular}{|r|l|}
\hline Journal: & Food Additives and Contaminants \\
\hline Manuscript ID: & TFAC-2009-212.R1 \\
\hline Manuscript Type: & Original Research Paper \\
\hline Author: & 09-Sep-2009 \\
\hline Complete List of Authors: & $\begin{array}{l}\text { Helling, Ruediger; Saxon Institute for Public and Veterinary Health } \\
\text { Kutschbach, Katja; TU-Dresden, Food Chemistry } \\
\text { Simat, Thomas; TU-Dresden, Food Chemistry }\end{array}$ \\
\hline Methods/Techniques: & Analysis - NMR \\
\hline Additives/Contaminants: & $\begin{array}{l}\text { Migration, Packaging - food simulants, Packaging - overall } \\
\text { migration, Rubber }\end{array}$ \\
\hline Food Types: & Infant formulae, Meat \\
\hline
\end{tabular}

\section{SCHOLARONE ${ }^{\text {m }}$ Manuscripts}




\begin{abstract}
Different foodstuffs were prepared in silicone baking moulds and were analyzed for siloxane migration using a previously developed and validated ${ }^{1} \mathrm{H}-\mathrm{NMR}$ method. Meat loaf was found to be a critical foodstuff which may significantly exceed the overall migration limit of $60 \mathrm{mg}$ $\mathrm{kg}^{-1}\left(10 \mathrm{mg} \mathrm{sdm}{ }^{-1}\right)$ in the first as well as in the third experiment. The highest siloxane migration found in a meat loaf after preparation in a commercial mould was $177 \mathrm{mg} \mathrm{kg}^{-1}$. In contrast, milk-based food showed only very low or non-detectable migration $\left(<2.4 \mathrm{mg} \mathrm{kg}^{-1}\right)$ even if consisting of higher fat amounts. Similar results were achieved when using $50 \%$ ethanol as the official simulant for milk-based products as defined in the Plastics Directive 2007/19/EEC. After solvent extraction of the moulds simulating long term usage, no further migration into the food was detectable, indicating that there is no relevant formation of low molecular weight, potentially migrating siloxanes from the elastomer. During repeated usage, the investigated moulds showed a high uptake of fat during the use of up to $8.0 \mathrm{~g}$ fat per $\mathrm{kg}$ elastomer. The proper tempering of the moulds exhibited a major influence on the migration properties of siloxanes into different foodstuffs. Non-tempered moulds with a high level of volatile organic compounds of $1.1 \%$ were shown to give considerably higher migration than the equivalent tempered moulds.
\end{abstract}

Keywords: Silicones, polydimethylsiloxanes, ${ }^{1} \mathrm{H}-\mathrm{NMR}$, migration, foodstuffs

\title{
Introduction
}

During the last decade flexible silicone moulds have achieved significant market share and are widely used in households as well as in commercial food production. Many advantages such as a non-sticky surface, flexible form and low weight as well as the general low toxicity of migrating polysiloxanes led to a broad acceptance of silicone materials in food contact situations (Wacker 2008). On the other hand, silicone elastomers are not very inert when in contact with fatty or oily foodstuffs and may show rather high migration compared to metal moulds (Forrest and Sidwell 2005, Helling et al. 2009). 
Different authors have described the interaction between silicone elastomers and foodstuffs. Earlier studies focused on the amount of volatile organic compounds as an indicator for potential high migration (Bannister et al. 1981, Lund et al. 2002). A limit of $0.5 \%$ for the release of volatile organic compounds was introduced to differ between tempered and nontempered materials and to avoid excessive migration (BfR recommendation XV). Later on gravimetric migration studies using the official substitute simulants for olive oil ethanol (95\%), isooctane and Tenax were performed (Forrest and Sidwell 2005, Meuwly et al. 2005). These studies only gave a first indication of the different temperature profiles in foodstuffs and simulants and of the different types of diffusion in simulants compared to foodstuffs such as cake, which change from nearly liquid to solid during the baking process. Using GCtechniques, linear and cyclic siloxane oligomers were identified as the main constituents of the migrate. Meuwly et al. (2005) used Tenax to demonstrate the strong temperature dependence of siloxane migration, and postulated a formation of low molecular weight oligomers during repeated heating and thus a regeneration of migrating compounds. GC-MS was discussed as a suitable method to determine the siloxane migration into complex food such as pizza. However, only a poor recovery of mid and high molecular weight oligomers (Meuwly et al. 2007, Helling et al. 2009) could be achieved. Until now the only described method for a reliable quantification of migrating siloxane oligomers in fatty foodstuffs is the ${ }^{1}$ H-NMR spectroscopy (Helling et al. 2009), despite various other methods having been described for biological samples such as tissues (Čavić-Vlasak et al. 1996, McCamey et al. 1986, Peters et al. 1995, Kennan et al. 1999, Dorn and Skelly 1994, Biggs et al. 1987).

A ${ }^{1}$ H-NMR spectroscopic method was developed and validated for determination of the migration of organosiloxanes from silicone materials into cake. It was also demonstrated, that the overall migrate as determined by gravimetric methods consists to more than $90 \%$ of organosiloxanes. Using this method it was shown that the results of migration experiments in simulants according to the time and temperature conditions as given in the plastics Directive (82/711/EEC) differ strongly from the siloxane amounts measured in food (Helling et al. 2009). Estimation of the siloxane content in food is essential for the correct assessment of the individual moulds. Especially for cake the overall migration limit of $60 \mathrm{mg} \mathrm{kg}^{-1}$ food or $10 \mathrm{mg}$ $\mathrm{sdm}^{-1}$, as defined in the Resolution ResAP (2004) 5 and in the Swiss legislation EDI, was respected - even in cases where migration experiments with simulants showed migration results were above the limit. In contrast to the migration studies carried out on simulants, the migration value in cake after multiple use of the mould tended to be almost constant, 
indicating different migration behaviour compared to the liquid simulants as well as Tenax ${ }^{\circledR}$. Moreover all test cakes baked in differently shaped moulds contained similar siloxane amounts which may result from a somewhat longer baking time needed in case of larger moulds, and thus equalizing the more advantageous volume/surface ratio (Helling et al. 2009). Less surprisingly, migration was found to rise with increasing fat content of a comparable cake or pizza and also with baking time and temperature (Helling et al. 2009, Meuwly et al. 2007).

Despite the initial data concerning siloxane migration in food, some questions remain: What could be a worst case scenario for migration into food and are the migration limits still respected? Are the tempering process and the previously introduced BfR limit for volatile organic compounds useful and necessary to avoid excessive migration values? Does a formation of siloxane oligomers happen during repeated and long heating process? How should silicone moulds for a long term use be assessed from a hygiene point of view? To find an answer to all these questions and to demonstrate the influence of proper tempering of silicone materials, more studies on silicone moulds were carried out, using again the ${ }^{1} \mathrm{H}-\mathrm{NMR}$ spectroscopic method to determine siloxane migration into food. Again, the focus was only on the overall migration analyzed via the NMR measured siloxane amount which is almost equal to the overall migration. Meatloaf as well as a milk based dessert (crème brulée) were chosen as possible critical foodstuffs and instant baby milk was used for additional testing of teats. Anthrachinone was introduced as an internal standard to have the opportunity to quantify the triglyceride content in the multiple used moulds (Malz 2003).

\section{Materials and Methods}

\section{Silicone moulds}

The silicone moulds used from various manufacturers were all bought on the German market except the moulds for the tempering study, which were provided by Wacker AG, Burghausen Germany. More detailed investigations concerning different food type experiments were carried out with a commercial 12 cups muffin silicone mould (volume: $95.8 \mathrm{~cm}^{3}$, inner surface: $0.86 \mathrm{sdm}$, thickness: $1.0 \mathrm{~mm}$, Pt catalyzed crosslinked) and a box shaped silicone mould (volume: $1300 \mathrm{~cm}^{3}$, inner surface: $5.8 \mathrm{sdm}$, thickness: $1.2 \mathrm{~mm}$, no information on crosslinking agents), both bought on the German market as well. 
The tempered / non-tempered moulds had a round shape (volume: $300 \mathrm{~cm}^{3}$, inner surface: 2.5 sdm, thickness: $1.5 \mathrm{~mm}$, Pt-catalyst for crosslinking). Teats (tempered and non-tempered, Ptcatalysed) have been donated by MAPA GmbH (Zeven, Germany).

All samples were first washed with warm water $\left(45-50^{\circ} \mathrm{C}\right)$ and household detergent, as recommended by the manufacturers.

\section{Chemicals}

All chemicals were obtained from Sigma-Aldrich Germany at analytical grade or higher. All food ingredients used for the baking studies were of commercial quality.

\section{Migration into food simulants ethanol $95 \%$ and ethanol $50 \%$}

$95 \%$ ethanol and and $50 \%$ ethanol were used as substitute simulants. The test conditions were based on common time-and-temperature conditions used for preparing the relevant foodstuffs and were selected according to Council Directive 82/711/EEC chapter $3 \mathrm{~N}^{\mathrm{o}} 1$ and table 4. As baking moulds are intended for repeated usage, the first, second and third overall migrate were determined in all cases (Commission Directive 2002/72/EC).

The tests were carried out as a 2 fold determination as described in part 14 of the European Standard EN 1186:2002: For migration tests with ethanol/water $95 / 5$ or 50/50 (v/v), the intact samples were brimfully filled with the preheated solvent $\left(60^{\circ} \mathrm{C}\right)$. In all cases, only the inside surface area of the moulds was assumed as contact area. Time measurement was already started when the samples were put into the oven, although the examination temperature of $60^{\circ} \mathrm{C}$ was regained later. An exposure time of 75 to $180 \mathrm{~min}$ depending of the size of the moulds was respectively chosen. The solvent was evaporated to determine the overall migration by the gravimetric standard method (EN 1186:2002).

\section{Migration into foodstuffs}

The studies were performed with creamed cake with $21 \%$ fat (as described previously by Helling et al. 2009) and meat loaf.

Creamed cake, $21 \%$ total fat (Das Backbuch, 1967)

The dough contained $125 \mathrm{~g}$ sunflower oil, $100 \mathrm{~g}$ egg (homogenized), $125 \mathrm{~g}$ sugar, $250 \mathrm{~g}$ wheat flour, $8 \mathrm{~g}$ baking powder and $50 \mathrm{~g}$ water.

Meat loaf, $14-19 \%$ total fat depending on the meat used

$500 \mathrm{~g}$ minced meat, $125 \mathrm{~g}$ onions, $75 \mathrm{~g}$ breadcrumbs, $30 \mathrm{~g}$ cheese and $3 \mathrm{~g}$ salt were carefully mixed. 


\section{Crème brulèe (milk-based sweet)}

Ingredients: $395 \mathrm{~g}$ cream, $80 \mathrm{~g}$ sugar, $70 \mathrm{~g}$ egg yolk, $8 \mathrm{~g}$ vanilla aromatised sugar.

Vanilla sugar and cream were cooked and added to a mixture of sugar and egg yolk. After intensive mixing, the mixture was poured into the mould and heated in a water bath in an oven at $175^{\circ} \mathrm{C}$ for $40 \mathrm{~min}$. After half the time of heating the moulds were covered with aluminium foil to avoid excessive browning. After the heating period the moulds were allowed to cool for 2 hours at $7^{\circ} \mathrm{C}$.

\section{Instant baby milk, $4.0 \%$ fat}

$22 \mathrm{~g}$ commercial instant baby milk powder was dissolved in $135 \mathrm{ml}$ bidistilled water at $50^{\circ} \mathrm{C}$. Teats were incubated in the preheated milk for 6 hours at $40^{\circ} \mathrm{C}$. (A longer test time could not be chosen because the instant milk was not stable for a longer time period.)

\section{Soxhlet extraction}

The foodstuffs were homogenized and an aliquot (approx. $12 \mathrm{~g}$ of the cake, $5 \mathrm{~g}$ of the meat loaf and $3 \mathrm{~g}$ of the Crème brulèe) was mixed thoroughly with sodium sulphate $\left(\mathrm{Na}_{2} \mathrm{SO}_{4}\right)$ in a mortar (approx. $15 \mathrm{~g}$ for cake and meatloaf, approx. $40 \mathrm{~g}$ for Crème brulèe and instant milk). The dry powder was transferred quantitatively into a Soxhlet cartridge and extracted for $6 \mathrm{~h}$ with $150 \mathrm{ml}$ diethyl ether in a Soxhlet extractor to isolate the fat matrix, including the siloxanes. At the end of the extraction, the diethyl ether was removed from the roundbottomed flask by distillation. Before and after extraction, the flask was dried repeatedly for 
$1 \mathrm{~h}$ at $103^{\circ} \mathrm{C}$ until constant weight was reached. The weight of the lipid extract was determined accurately to $0.1 \mathrm{mg}$.

Sodium sulphate had to be annealed for $3 \mathrm{~h}$ at $550{ }^{\circ} \mathrm{C}$ in a muffle furnace prior to use to remove siloxane impurities left over from manufacturing. Soxhlet cartridges and filter papers (used to clean the mortar and pestle and for filtration of the $\mathrm{CDCl}_{3}$ solution, respectively) were extracted thoroughly in a Soxhlet extractor with diethyl ether prior to use.

For recovery experiments instead of the minced meat, tartare was mixed with in total $17 \%$ lard, containing a known amount of polysiloxanes.

\section{NMR measurement of fat extracts}

For NMR measurement, $400 \mathrm{mg}$ of the extracted fat were dissolved in $800 \mu \mathrm{l} \mathrm{CDCl}_{3}$, filtered through silicone free paper and transferred into a NMR tube. The ${ }^{1} \mathrm{H}-\mathrm{NMR}$ spectra were recorded at $500 \mathrm{MHz}$ on a DRX $500 \mathrm{P}$ NMR spectrometer (Bruker). Parameter settings were as follows: temperature: $22^{\circ} \mathrm{C}$, number of scans: 128 , spectral width: $10330 \mathrm{~Hz}$, acquisition time: $3.17 \mathrm{~s}$, resolution: $0.158 \mathrm{~Hz}$ per point, frequency sample rotation: $20 \mathrm{~Hz}$, pulse delay: 1 s, pulse angle: $30^{\circ}$. Tetramethylsilane (TMS) was not added as a position standard for the chemical shift. Instead of this, the solvent signal $\left(\delta\left(\mathrm{CHCl}_{3}\right)=7.25 \mathrm{ppm}\right.$ in relation to TMS $)$ was used to ascertain the position of resonance bands.

Calculation of the siloxane content using the triglyceride signal as an internal standard was described previously (Helling et al. 2009).

\section{Determination of the amount of extractable substances of the box shaped mould}

$8 \mathrm{~g}$ of the silicone elastomer were cut into small pieces $(3 \times 3 \mathrm{~mm})$ and extracted with diethyl ether for 10 hours using a soxhlett unit. The residue was dried at $103^{\circ} \mathrm{C}$ for 2 hours, weighted and $200 \mathrm{mg}$ sunflower oil was added as an internal standard. The mixture was dissolved in 1 $\mathrm{ml} \mathrm{CDCl}_{3}$ and used for NMR measurement. The amount of extractable dimethyl siloxanes was $1.9 \%$.

\section{Complete extraction of the intact mould}

The box shaped mould was cleaned after the 10fold baking experiment with meatloaf and filled completely with ethanol. (Diethyl ether was not used to avoid irreversible swelling of 


\section{Determination of the incorporated fat of the silicone elastomer}

Approx. $50 \mathrm{~cm}^{2}$ of the silicone elastomer were cut into small pieces $(3 \times 3 \mathrm{~mm})$ and extracted with diethyl ether for 10 hours using a soxhlett unit. The residue was dried at $103^{\circ} \mathrm{C}$ for 2 hours, weighted and $100 \mu \mathrm{l}$ of internal standard anthrachinone $\left(5 \mathrm{mg} \mathrm{ml}^{-1}\right.$ in $\left.\mathrm{CDCl}_{3}\right)$ were added. The mixture was dissolved in $1 \mathrm{ml} \mathrm{CDCl}_{3}$ and used for NMR measurement. Calculation of the amount of triglycerides was done using the protons at $\mathrm{C} 1$ and $\mathrm{C} 3$ of the glycerin backbone as described for the determination of siloxanes with triglyceride as an internal standard.

\section{Volatile organic compounds}

To determine the amount of volatile organic compounds $10 \mathrm{~g}$ of the elastomer were cut into pieces of $1 \times 2 \mathrm{~cm}$ and conditioned over dried $\mathrm{CaCl}_{2}$ for 48 hours. Afterwards $10 \mathrm{~g}$ were weighted with a precision of $0.1 \mathrm{mg}$ into a glass bowl and heated for 4 hours at $200^{\circ} \mathrm{C}$, conditioned in an exsiccator and weighted again. The loss of weight calculated in percent gives the amount of volatile organic compounds.

\section{Results and discussion}




\section{Meatloaf}

The method used was validated previously for muffins (Helling et al. 2009) but a sufficient recovery rate was demonstrated again for meatloaf as described in the materials and method part and found to be at $(103.1 \pm 3.4) \%$. A blank sample of a meatloaf baked in a coated metal mould amounted to $1.9 \mathrm{mg}$ siloxane per $\mathrm{kg}$. This may result from the foodstuffs used as ingredients. Pork meat can be especially contaminated during industrial processing when exposed to a certain amount of siloxane. All equipment and chemicals used were shown to be almost free of siloxane contamination.

In a first experiment the influence of the baking time was investigated for meatloafs. Three pieces of meatloaf were baked in the same cup-sized mould one after another at a temperature of $175^{\circ} \mathrm{C}$ for 25 or $45 \mathrm{~min}$. Both foodstuffs differed in the grade of browning but were visually appealing and tasty. In the baking series at 25 min migration tended to increase or stay constant at a level between 55 and $92 \mathrm{mg} \mathrm{kg}^{-1}$, whereas the migration experiments at 45 min resulted in a much higher but decreasing migration from 177 to $135 \mathrm{mg} \mathrm{kg}^{-1}$. Baking time seems not only to influence the level of migration but also the migration behaviour during multiple use.

"[Insert Figure 1 about here]"

An identical mould was used in a previous study for muffins (Helling et al. 2009). The actual experiment with meatloaf resulted in migration values 5 to 18 fold higher compared to those achieved for muffins and cake in the previous study. It is noticeable that the migration values are much higher for meatloaf, although its fat content is somewhat lower. Since it is not typical to prepare meatloaf in a muffin mould, a box shaped mould with a volume of $1300 \mathrm{ml}$ was used for further experiments. To compare the results again with bakery products a creamed cake was baked twice in an identical box shaped mould and gave migration values in the expected range at both $10.0 \mathrm{mg} \mathrm{kg}^{-1}\left(1.9 \mathrm{mg} \mathrm{sdm}^{-1}\right)$. The overall migration limit was exceeded again when preparing a meatloaf in this mould $\left(87.8 \mathrm{mg} \mathrm{kg}^{-1}\right.$ and $\left.15.2 \mathrm{mg} \mathrm{sdm} \mathrm{sm}^{-1}\right)$. The impressive migration compared to cake may be explained by the leaking fat which extracts siloxane oligomers much more effectively than dough and may also affect a swelling of the silicone material.

“[Insert Figure 2 about here]” 
A baking sequence was performed to the $10^{\text {th }}$ migrate. For experiment 4,6 and 8 the leaking fat was separated from the meatloaf and both analysed separately. The amount of siloxane oligomers in the liquid fat was at 1330, 1088 and $813 \mathrm{mg} \mathrm{kg}^{-1}$ and therefore about 30-fold above the amount measured in the meat $\left(41,40\right.$ and $\left.26 \mathrm{mg} \mathrm{kg}^{-1}\right)$.

A slight decrease in the migration values was observed from the $1^{\text {st }}$ to $10^{\text {th }}$ migrate. If judged according to the $3^{\text {rd }}$ migrate as claimed for plastics (Commission Directive 2002/72/EC), the investigated mould exceeded the overall migration limit as defined in the Resolution ResAP (2004) 5 on silicones used for food contact applications. On the other hand, rejecting the leaked fat before consuming the food gives a good opportunity to avoid higher contaminated meals.

\section{"[Insert Figure 3 about here]"}

Although migration from $1^{\text {st }}$ to $10^{\text {th }}$ experiment shows a slight tendency to decrease, there are much greater variations between successive steps. The main reason is the variation in the fat content of the used meat, which effects the resulting migration quite strongly. This is difficult to avoid because minced meat standardized in fat was not available.

Because there was high migration even in the $10^{\text {th }}$ experiment, it was of great interest, whether the migration would decrease to negligible values or siloxane oligomers would arise during long term use because of thermal and oxidative stress as described by Meuwly et al (2005).

Total extraction of a similar mould with diethyl ether resulted in $1.9 \%$ or $2.57 \mathrm{~g}$ extractable siloxanes per mould. The sum of all ten migration experiments yielded $460 \mathrm{mg}$ (18\% of the totally extractable siloxanes). To shorten the ongoing experiment, further baking was stopped and the previously used mould was filled with ethanol and incubated at $60^{\circ} \mathrm{C}$ until no further siloxanes could be extracted. At the end of this extraction the mould became somewhat rough and frangible and the original blue colour faded out.

"[Insert Figure 4 about here]" 
At this point a 2 fold baking experiment with the same meatloaf recipe was performed to demonstrate if siloxane chains were cracked and new oligomers were built and released. In both cases no migration of siloxanes could be detected (limit of detection $1 \mathrm{mg} \mathrm{kg}^{-1}$ ). Compared to the migration values during the first 10 baking cycles, it can be concluded that no significant formation of low molecular weight and freely available siloxanes occurred. Furthermore it must be pointed out that during the last baking procedure, the mould became even more frangible and started leaking. No further use was possible. It can be speculated that low and mid-size cyclic siloxanes act as plasticizers and are of some importance for the functionality and the elasticity of the polymer. At least if all those oligomers are migrated the mould might no longer be useable. Significant new formation of oligomers did not occur.

\section{Milk products}

To assess another kind of food, a milk-based dessert (crème brulèe) was prepared. Again the recovery rate was proven before and found to be lower than for cake and meatloaf but still to be analytically suitable $(88.5 \%)$. The limit of detection for this dessert was determined at 2.4 $\mathrm{mg} \mathrm{kg}^{-1}$.

It has to be mentioned that the time of preparation for crème brulèe in the moulds is clearly longer than for the other investigated foodstuffs. But due to the high water content, the preparation procedure (water bath) and the fat in water emulsion type, the temperature at the contact surface between mould and food will not rise above $100^{\circ} \mathrm{C}$. There are obviously no significant amounts of free fat despite the pretty high fat content of $27 \%$ in total.

A 3 fold determination of each of 5 subsequent migration experiments (one after another) was done. In all cases, except the $3^{\text {rd }}$ migrate, the amount of migrated siloxane was below the limit of detection $\left(2.4 \mathrm{mg} \mathrm{kg}^{-1}\right)$. For the $3^{\text {rd }}$ migrate, the limit of detection was exceeded slightly but no reliable quantification could be done.

Similar results were obtained for silicone teats incubated in instant baby milk for 6 hours at $40^{\circ} \mathrm{C}$. Again no migration above the limit of detection of $2.4 \mathrm{mg} \mathrm{kg}^{-1}$ could be detected using the described NMR-method.

Thus, due to the already investigated foodstuffs muffin and cakes, pizza, meat loaf, milk based sweets and food (Meuwly et al. 2007, Helling et al. 2009) it can be concluded, that 
exceeding the overall migration limit may only occur in case of foodstuffs with free available and liquid fat at temperatures well above $100^{\circ} \mathrm{C}$ as for instance meatloaf and soufflés / gratin.

To compare once more the situation in food and simulants, it was investigated whether the very low migration into milk-based food was adequately simulated by the use of an ethanol / water mixture (50 \%) as a simulant for milk as introduced by Directive 2007/19/EEC.

7 moulds were analyzed gravimetrically using the substitute simulants $95 \%$ ethanol and $50 \%$ ethanol. Table 1 lists the results: In some cases migration into $50 \%$ ethanol was not detectable, in other cases only a low migration compared to ethanol $95 \%$ and tenax was measured. In contrast to the other simulants for fatty foodstuffs, the migration limit of $10 \mathrm{mg}$ $\mathrm{sdm}^{-1}$ was never reached or exceeded. This accords strongly with the already described study with instant milk and milk-based sweets and in this special case confirms the suitability of 50 $\%$ ethanol as a simulant.

\section{"[Insert Table 1 about here]"}

\section{Influence of the tempering process on migration properties}

Tempered and the corresponding non-tempered silicone moulds were received from Wacker Chemie AG (Burghausen, Germany) to demonstrate the influence of the tempering on the overall migration in both cake and meat loaf.

The amount of volatile organic compounds is often used as a parameter to check adequate tempering (RASFF) and is regulated within BfR-recommendation XV to a limit of $0.5 \%$. This is based on the demand that volatile compounds should be eliminated before use of the moulds. Otherwise they could both migrate or evaporate and recondensate on the surface of the food.

The non-tempered moulds showed an amount of $1.11 \%$ volatile organic compounds, which is clearly above the BfR limit, whereas the tempered moulds yielded only very low $0.07 \%$. Earlier investigation programs of the official food control authority in Saxony demonstrated that common silicone moulds have in general volatile organic compounds between 0.2 and 0.4 $\%$.

“[Insert Figure 5 about here]” 
Figure 5 shows a comparison of the tempered and non-tempered moulds for cake and meatloaf. Surprisingly, the overall migration in creamed cake in the non-tempered mould was for all 3 migration experiments 8 - 9 fold higher than in the tempered mould, resulting in a first time measured migration well above $60 \mathrm{mg} \mathrm{kg}^{-1}$ for cake. In contrast to the previous studies with tempered forms from the market, a decrease of the migration from $1^{\text {st }}$ to $3^{\text {rd }}$ experiment was observed also for creamed cake.

Preparation of meatloaf in the untempered moulds also resulted in very high migration values up to $281 \mathrm{mg} \mathrm{kg}^{-1}$ but only 2.5 to 3 fold higher as measured in the tempered moulds.

Thus, appropriate tempering seems to be essential to achieve low migration values for silicone baking moulds. Analyzing the amount of volatile organic compounds according to BfR recommendation $\mathrm{XV}$ can give some reliable hints of what migration values should be expected. But from this single experiment it cannot be stated whether the actual limit of $0.5 \%$ for volatile organic compounds is low enough to avoid excessive migration or not. As our results for 201 moulds from the German market (analyzed from 2004 - 2009) indicate, lower values than $0.5 \%$ could be easily achieved.

“[Insert Figure 6 about here]"

\section{Enrichment of fat in the silicone material}

In all baking experiments migration of fat originating from the food into the silicone polymer was observed. After some baking cycles fat sweated out, even on the outside of the moulds used. Moulds which were not used for a while and stored at room temperature for about six months exhibited a typical and unpleasant odour of oxidised (rancid) fat. As to be expected, extensive washing and cleaning could not remove the incorporated fat from the moulds. To estimate what amount of fat was incorporated into the polymer, diethyl ether extraction and quantification of the fat using again ${ }^{1} \mathrm{H}-\mathrm{NMR}$ spectroscopy was done for 2 different moulds, both after repeated preparation of cake or meat loaf.

The obtained values were in the range from 3.5 to $5.9 \mathrm{~g}$ fat per $\mathrm{kg}$ elastomer and did not show a significant difference between the moulds used for cake or meatloaf. Outside this range and with the highest fat content, the mould used for the long-term baking experiment with meatloaf (including total extraction of the siloxanes) the following was found: $8.0 \mathrm{~g} \mathrm{~kg}^{-1}$ fat was measured in the polymer. Because all free available substances were extracted with 


\section{Conclusion}

Different types of food were prepared in silicone moulds of different sizes and shapes. The main result is that the type of food and availability of fat is the most important criteria for the amount of migration. The total fat content is only of relevance if similar foodstuffs are compared. In our studies meatloaf with a total fat content of about $17 \%$ was the worst case in the field of migration and the only food to exceed the overall migration limit as stated in the Resolution ResAP (2004) 5 on silicones used for food contact applications or in the Swiss legislation EDI. In contrast creamed cake with a similar baking time and temperature and with up to $30 \%$ fat or a milk-based dessert (crème brulèe) with even longer heating time and $27 \%$ fat showed a much lower or even non detectable migration. This applied both for small and larger moulds with a very different surface / volume ratio.

Preparing cake or milk-based desserts as well as the use of silicone teats for baby feeding will typically not lead to an excessive migration of siloxane oligomers, which exceed the overall migration limit. On the other hand, it must be concluded that most silicone moulds are not suitable for preparing meatloaf or gratins with larger portions of free available fat if judged according to the criteria of the Resolution ResAP (2004) 5. Preparation of roasts, gratins and similar foodstuffs should not be recommended or even better excluded within the declaration of silicone moulds. Although the overall migration limit will be exceeded in case of the preparation of those foodstuffs, no toxicolocigal concern exists so far.

Testing silicone moulds with simulants such as Tenax ${ }^{\circledR}$ instead of foods does not give a realistic scenario and is not suitable for judging legal compliance. Tests with simulants commonly focus on the total fat content of foodstuffs and suggest reducing factors to 
compensate a lower fat content compared to olive oil or simulants. As shown in this and previous studies, the total fat content is only one of several parameters to look at and the amount of the overall migration depends strongly on the type of food, the kind of emulsion and further aspects. As mentioned in Article 3 of the framework Regulation (EC) 1935/2004, it is important to assess and overweight the amount of migrating substances in food, but not in simulants (except if it can be shown, that the simulants reflect the situation in the foodstuffs in a realistic manner).

In general, migration from silicone elastomers into food seems to be nearly constant in the beginning but slightly decreasing with ongoing use. No additional formation of low molecular weight silixone oligomers during repeated heating could be observed. This stands in contrast to the previously published work of Meuwly et al (2005) and requires further investigation. Eventually the fat incorporated during the preparation of food acts as an oxygen scavenger, and thus prevents oxidative cleavage of the silicone chains during heating. Further studies that focus on this particular question are already in progress.

Adaqueate tempering was shown to be essential to guarantee a low migration for all types of food. Analyzing the amount of volatile organic compounds can give a good indication of the need for further migration studies to examine an individual mould.

Another critical point of silicone moulds compared to the traditional metal coated ones is the uptake of food originated fat, which can lead in some cases to organoleptic and hygienic faults. An exchange of odorous moulds is strongly recommended.

\title{
Acknowledgement
}

The authors would like to thank the Centre Européen des Silicones (Brussels, Belgium) for financial support of the studies and helpful advice. We also gratefully acknowledge Dr. Margit Gruner and Annett Rudolph (Technical University of Dresden, Institute of Organic Chemistry) for doing numerous NMR measurements.

\author{
References \\ Bannister D J, Semlyen J A. 1981. Studies of cyclic and linear poly(dimethylsiloxanes) : 6. \\ Effect of heat. Polymer 22.
}


Biggs RB, Fetzer JC, Brown RJ. 1987. Determination of Silicon Compounds by Gradient Liquid Chromatographic Separation with Direct Current Plasma Atomic Emission Spectrometric Detection. Anal. Chem. 59. 2798-2802

Čavić-Vlasak BA, Thomson M, Smith DC. 1996. Silicones and their determination in biological matrices. A review. Analyst 121. 53R-63R

Commission Directive 2002/72/EC of 6 August 2002 relating to plastic materials and articles intended to come into contact with foodstuffs. Official Journal of the European Communities, L 220, 2002 August 15, p. 18-58

Commission Directive 2007/19/EC of 30 March 2007 amending Directive 2002/72/EC relating to plastic materials and articles intended to come into contact with food and Council Directive 85/572/EEC laying down the list of simulants to be used for testing migration of constituents of plastic materials and articles intended to come into contact with foodstuffs. Official Journal of the European Communities, L 091, 2007 March 31, p. 17-36

Council Directive 82/711/EEC of 18 October 1982 laying down the basic rules necessary for testing migration of the constituents of plastic materials and articles intended to come into contact with foodstuffs. Official Journal of the European Communities, L 297, 1982 October 23, p. $26-30$

Council Directive 85/572/EEC of 19 December 1985 laying down the list of simulants to be used for testing migration of constituents of plastic materials and articles intended to come 
into contact with foodstuffs. Official Journal of the European Communities, L 372, 1985

December 315, p. 14-21

Council Directive 89/107/EEC of 21 December 1988 on the approximation of the laws of the Member States concerning food additives authorized for use in foodstuffs intended for human consumption. Official Journal of the European Communities, L 40, 1989 February 11, p. 2733.

Dorn SB, Skelly Frame EM. 1994. Development of a high-performance liquid chromatographic-inductively coupled plasma method for speciation and quantification of silicones: From silanols to polysiloxanes. Analyst 119. 1687-1694

Food Migrosure project. Modelling Migration from plastics into foodstuffs as a novel and cost efficient tool for estimation of consumer exposure from food contact material.

Available from:

http://www.foodmigrosure.com/. Accessed 2008, July 17.

Forrest MJ, Holding SR, Howells D, Eardley M. 2006. The use of GCxGCTOFMS and LC-MS for the determination of migrants from silicone rubbers into food simulants and food products. Silicone Elastomers, 19-20 September 2006, Frankfurt Germany (oral contribution)

Forrest MJ, Sidwell J. 2005. Chemical migration from silicones used in connection with food contact materials and articles (Food Standard Agency Contract Number A03046)

GFK Panel Services Germany [internet]. Available from:

http://www.gfk.com/imperia/md/content/ps_de/chart_der_woche/kw49_06_silikonbackforme n.pdf. Accessed 2007, April 15.

Helling R, Mieth A, Altmann S, Simat TJ. 2009. Determination of the overall migration from silicone baking moulds into simulants and food using ${ }^{1} \mathrm{H}-\mathrm{NMR}$ techniques. Food Additives and Contaminants 26/3. 395-407 
Kala SV, Lykissa ED, Lebovitz RM. 1997. Detection and characterization of poly(dimethyl)siloxanes in biological tissues by GC/AED and GC/MS. Anal. Chem. 69. $1267-1272$

Kennan JJ, McCann Breen LL, Lane TH, Taylor RB. 1999. Methods for Detecting Silicones in Biological Matrixes. Anal. Chem. 71. 3054-3060

Kim HJ; Kim SH, Lee CH, Nah J-W, Hahn A. 2003. DEHP Migration Behavior from Excessively Plasticized PVC Sheets. Bull Korean Chem. Soc. 24/3. 345-349

Lund K H, Petersen J H. 2002. Safety of food contact silicone rubber: Liberation of volatile compounds from soothers and teats. Eur Food Res Technol 214. 429-434

Malz F. Quantitative NMR-Spektroskopie als Referenzverfahren in der analytischen Chemie. Dissertation Humboldt Universität Berlin. 2003

McCamey DA, Iannelli DP, Bryson LJ and Thorpe TM. 1986. Determination of silicone in fats and oils by electrothermal atomic absorption spectrometry with in-furnace air oxidation. Analytica chimica acta 188. 119-126

Meister Verlag (Ed.) 1999. Backen und Genießen. Munich: Meister Verlag

Meuwly R, Brunner K, Fragnière C, Sager F, Dudler V. 2005. Heat stability and migration from silicone baking moulds. Mitt. Lebensm. Hyg. 96. 281-297

Meuwly R, Sager F, Brunner K, Dudler V. 2007. Migration of siloxane oligomers in foodstuffs from silicone baking moulds. Deutsche Lebensmittel-Rundschau 103. 12/2007. 561-568.

Mojsiewicz-Pieńkowska K, Jamrógiewicz Z, Łukasiak J. 2003. Determination of polydimethylsiloxanes by ${ }^{1} \mathrm{H}-\mathrm{NMR}$ in wine and edible oils. Food Additives and Contaminants 20. $438-444$ 
Peters W, Smith D, Lugowski S, McHugh A, Baines C. 1995. Do patients with silicone-gel breast implants have elevated levels of blood silicon compared with control patients? Annals of Plastic Surgery 34. 343-347

Rapid Alert System for Food and Feed (RASFF). Available from: http://ec.europa.eu/food/food/rapidalert/index_en.htm. Accessed 2009, March 06.

Regulation (EC) No 1935/2004 of the European Parliament and of the Council of 27 October 2004 on materials and articles intended to come into contact with food and repealing Directives 80/590/EEC and 89/109/EEC. Official Journal of the European Communities, L 338, 2004 November 13, p. 4-17

Resolution AP (2004) 5 on silicones used for food contact applications. Council of Europe. Public Health Committee. Committee of experts on materials coming into contact with food. 2004 June 10. Available from:

http://www.coe.int/t/e/social_cohesion/soc\%2Dsp/public_health/food_contact/Resolution\%20 AP\%20_2004_\%205\%20on\%20silicones.pdf. Accessed 2007, November 22.

Synoptic Document. Provisional list of monomers and additives notified to European Commission as substances which may be used in the manufacture of plastics or coatings intended to come into contact with foodstuffs. SANCO D3/AS D (2005). Version from 2005 July 25. Available from:

http://ec.europa.eu/food/food/chemicalsafety/foodcontact/synoptic_doc_en.pdf. Accessed 2008, May 30.

Verlag für die Frau (Ed.) 1967. Das Backbuch. $1^{\text {st }}$ edition. Leipzig: Verlag für die Frau Verordnung des EDI vom 23. November 2005 über Bedarfsgegenstände, Stand 1. April 2008 (SR 817.023.21). Available from: http://www.admin.ch/ch/d/sr/c817_023_21.html. Accessed 2008, May 06.

Vincent GA, Tonge JS. 2000. Methods of making alkoxylated resin-polymer organosilicone networks and products obtainable therefrom. Eur. Pat. Appl. EP 1083195 A1 
Wacker-Homepage. silicone - Problemlösungen im Haushalt. Available from: http://www.wacker.com. Accessed 2008, May 06. 
Table I. Determination of the overall migration with ethanol 50\% as a simulant for milk compared to ethanol $95 \%$ and Tenax as the most common simulants for fatty foodstuffs.

\begin{tabular}{|c|c|c|c|c|c|c|c|c|}
\hline \multirow[t]{2}{*}{ Type } & \multicolumn{2}{|c|}{$\begin{array}{l}\text { Migration with ethanol } \\
50 \%\left[\mathrm{mg} \mathrm{dm}^{-1}\right]\end{array}$} & \multicolumn{2}{|c|}{$\begin{array}{l}\text { Migration with ethanol } \\
95 \%\left[\mathrm{mg} \mathrm{dm}^{-1}\right]\end{array}$} & \multirow[t]{2}{*}{$\begin{array}{l}\text { test conditions for } \\
\text { ethanol }(\mathrm{t} / \mathrm{T})\end{array}$} & \multicolumn{2}{|c|}{$\begin{array}{c}\text { Migration with Tenax } \\
{\left[\mathrm{mg} \mathrm{dm}^{-1}\right]}\end{array}$} & \multirow[t]{2}{*}{$\begin{array}{c}\text { test conditions for } \\
\text { Tenax }(\mathrm{t} / \mathrm{T}) \\
\end{array}$} \\
\hline & 1st migrate & 3rd migrate & 1st migrate & 3rd migrate & & 1st migrate & 3rd migrate & \\
\hline large mould for king`s cake A & 0,6 & 0,5 & 36,5 & 15,7 & $180 \min 60^{\circ} \mathrm{C}$ & 25,3 & 15,4 & $60 \min 175^{\circ} \mathrm{C}$ \\
\hline large mould for king`s cake B & n.d. & n.d. & 30,6 & 24,9 & $180 \min 60^{\circ} \mathrm{C}$ & 35,0 & 15,0 & $60 \min 175^{\circ} \mathrm{C}$ \\
\hline Madeleine type mould & 4,6 & 3,2 & 42,0 & 14,3 & $75 \mathrm{~min} 60^{\circ} \mathrm{C}$ & 29,2 & 15,9 & $60 \min 175^{\circ} \mathrm{C}$ \\
\hline muffin mould A (6 cups) & n.d. & n.d. & 18,2 & 22,2 & $75 \min 60^{\circ} \mathrm{C}$ & 20,0 & 14,2 & $25 \min 175^{\circ} \mathrm{C}$ \\
\hline muffin mould B (6 cups) & 3,7 & 1,2 & 25,3 & 8,1 & $75 \min 60^{\circ} \mathrm{C}$ & 25,8 & 16,3 & $25 \min 175^{\circ} \mathrm{C}$ \\
\hline muffin mould C (6 cups) & 1,4 & 1,3 & 58,6 & 25,1 & $75 \min 60^{\circ} \mathrm{C}$ & 17,5 & 10,0 & $25 \min 175^{\circ} \mathrm{C}$ \\
\hline muffin mould D (8 cups) & n.d. & n.d. & 20,4 & 17,7 & $75 \min 60^{\circ} \mathrm{C}$ & 11,3 & 5,9 & $25 \min 175^{\circ} \mathrm{C}$ \\
\hline
\end{tabular}

n.d. - not detectable (the limit of detection and quantification for the gravimetric method is $0.5 \mathrm{mg} \mathrm{dm}^{-1}$ ). 


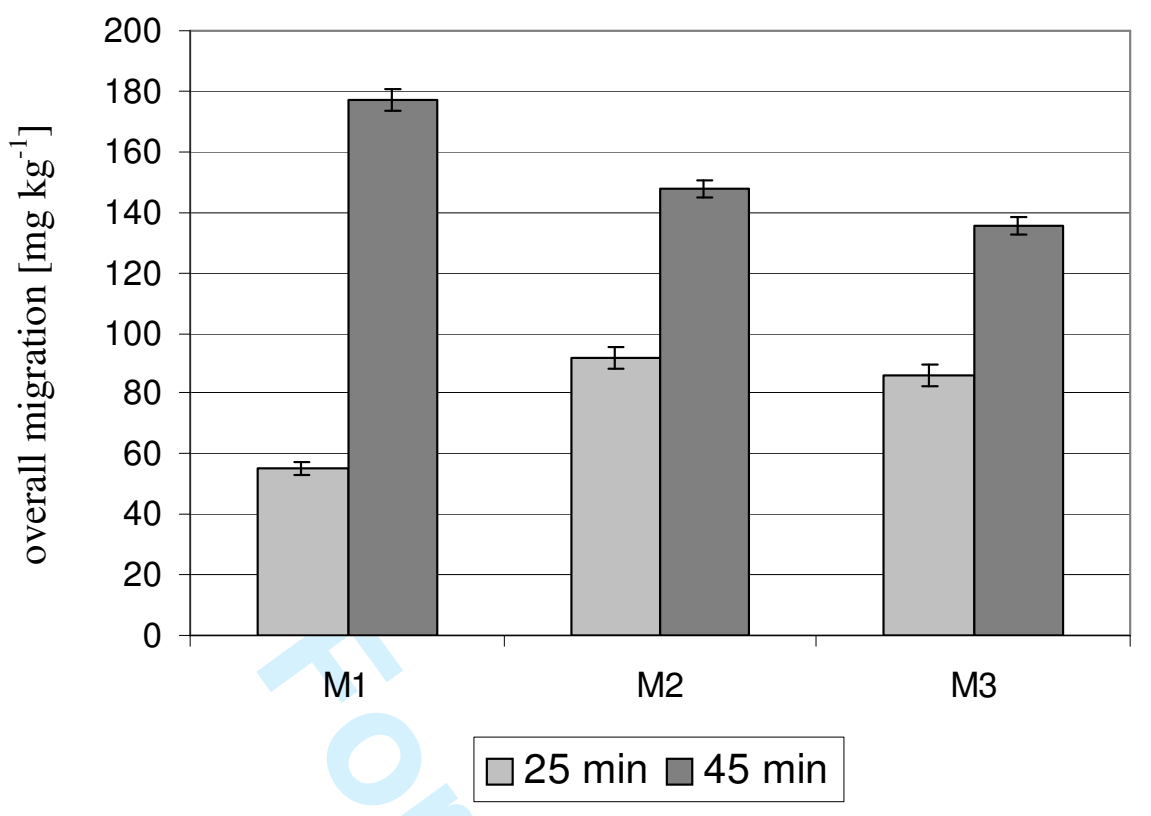

Figure 1. Overall migration in dependence on the baking time of meat loaf prepared in a small round shaped silicone mould. Data given for first (M1), second (M2) and third (M3) baking process. All data are based on a 3 fold determination. 


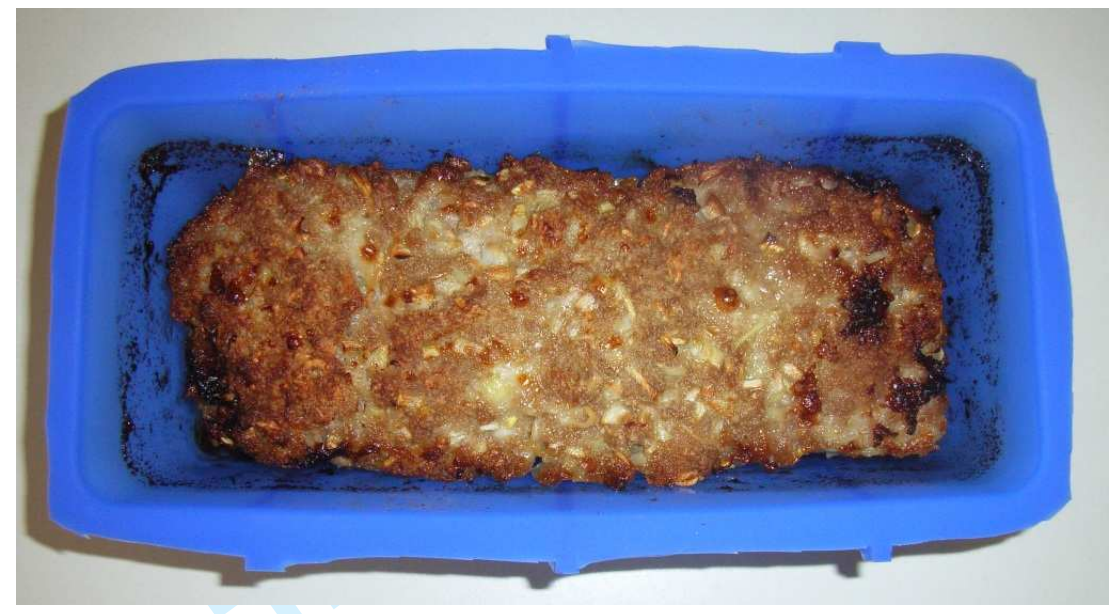

Figure 2. Picture of a typical meat loaf prepared in a box shaped silicone mould as done 10 | times one after another for repeated migration studies. 


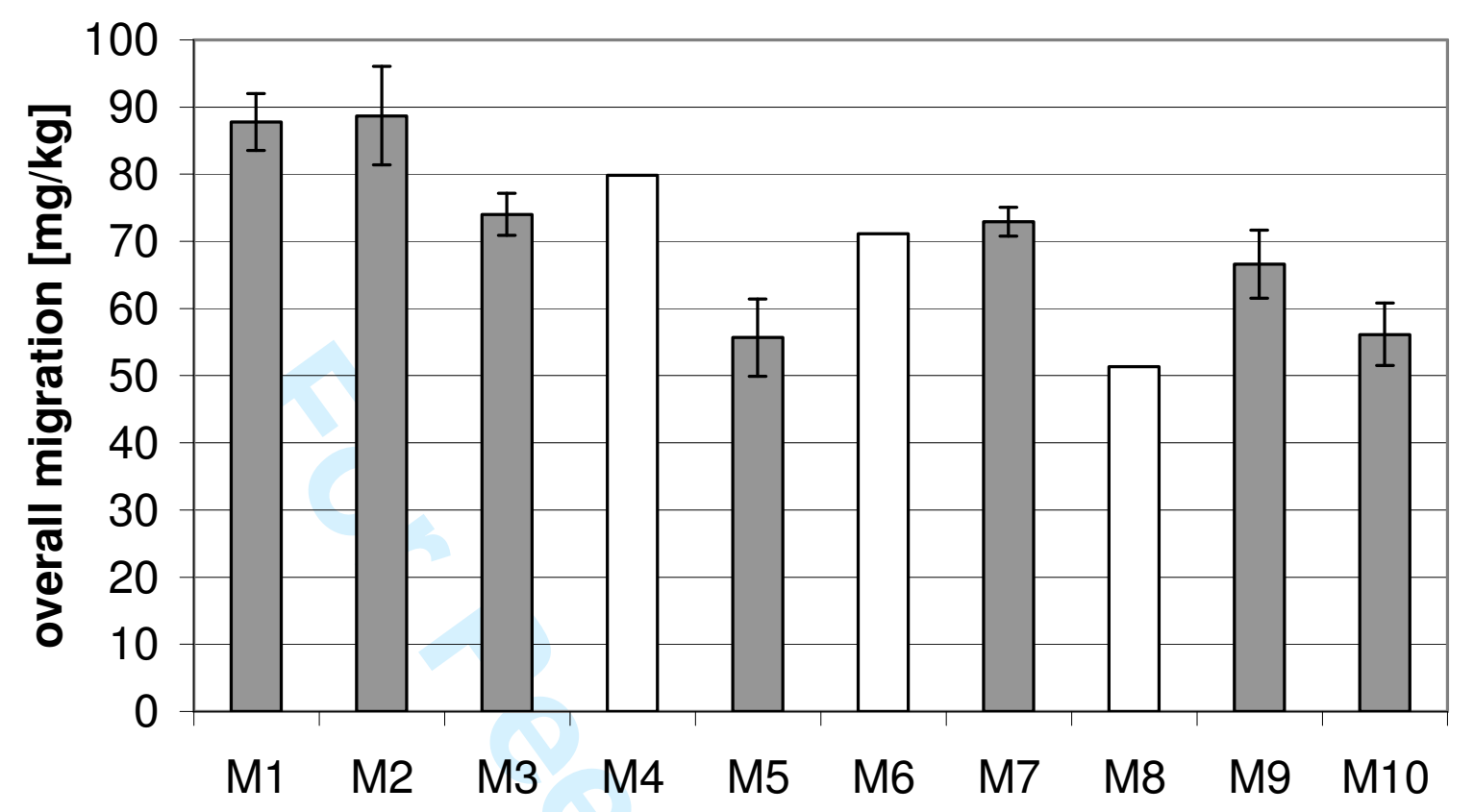

Figure 3. Overall migration of meat loaf prepared 10 times (M 1- 10) in a box shaped silicone mould. Differences in the overall migration occurred partly due to differences in the fat content of the meat used (14-19\% fat). M 5 was the foodstuffs lowest in fat. For samples M 4, M 6 and M 8 sauce and meat loaf were analyzed separately and the sum used for calculation of the overall migration. For these, $20 \mathrm{~g}$ of sauce contained as much siloxanes as aprox. $640 \mathrm{~g}$ meat loaf. All together $0,46 \mathrm{~g}$ siloxanes were extracted with those 10 experiments. 
Figure 4. Picture of the bottom of the box shaped silicone mould after 10 migration experiments with meat loaf, complete extraction of remaining unbound siloxanes with ethanol and another baking procedure. The elastomers colour faded out, the elastomer itself became rough and frangible. During the next experiment the mould started leaking and could not be used further. 


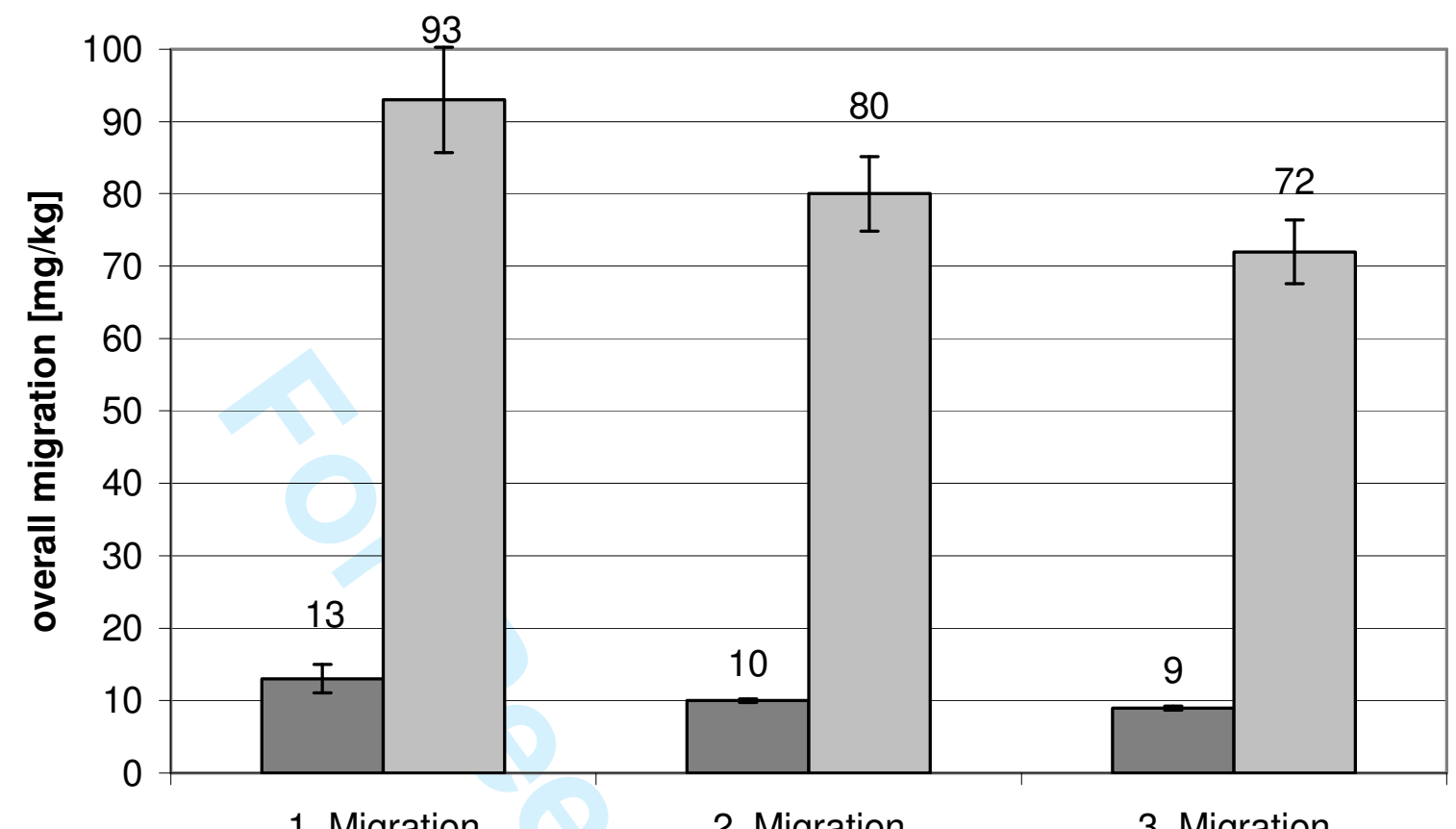

1. Migration

2. Migration

3. Migration

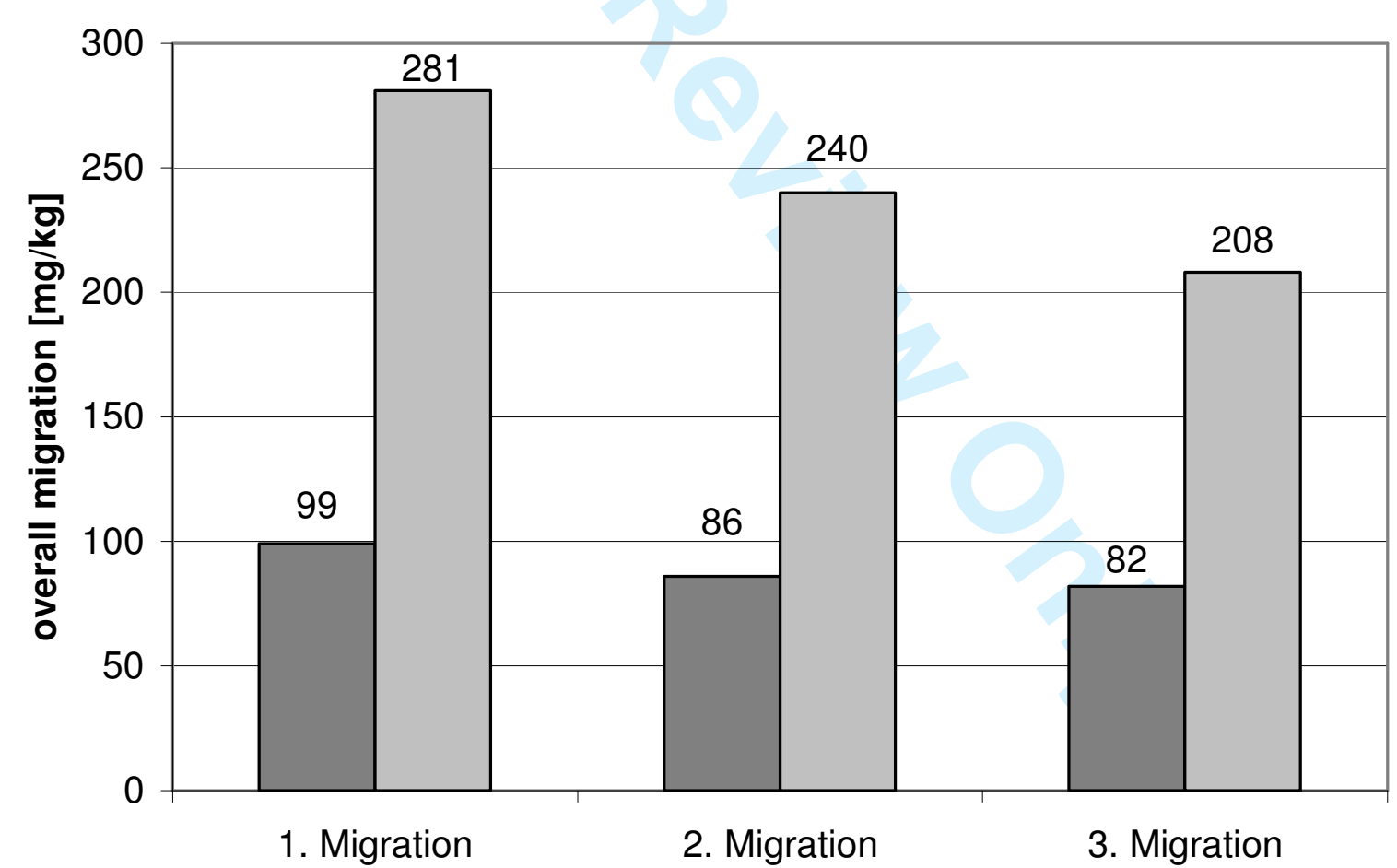

Figure 5 a) Migration in creamed cake (21\% fat) b) Migration in meat loaf (aprox. $17 \%$ fat); both $1^{\text {st }}-3^{\text {rd }}$ migration shown: dark columns represent the tempered moulds whereas the lighter columns stand for the untempered moulds 


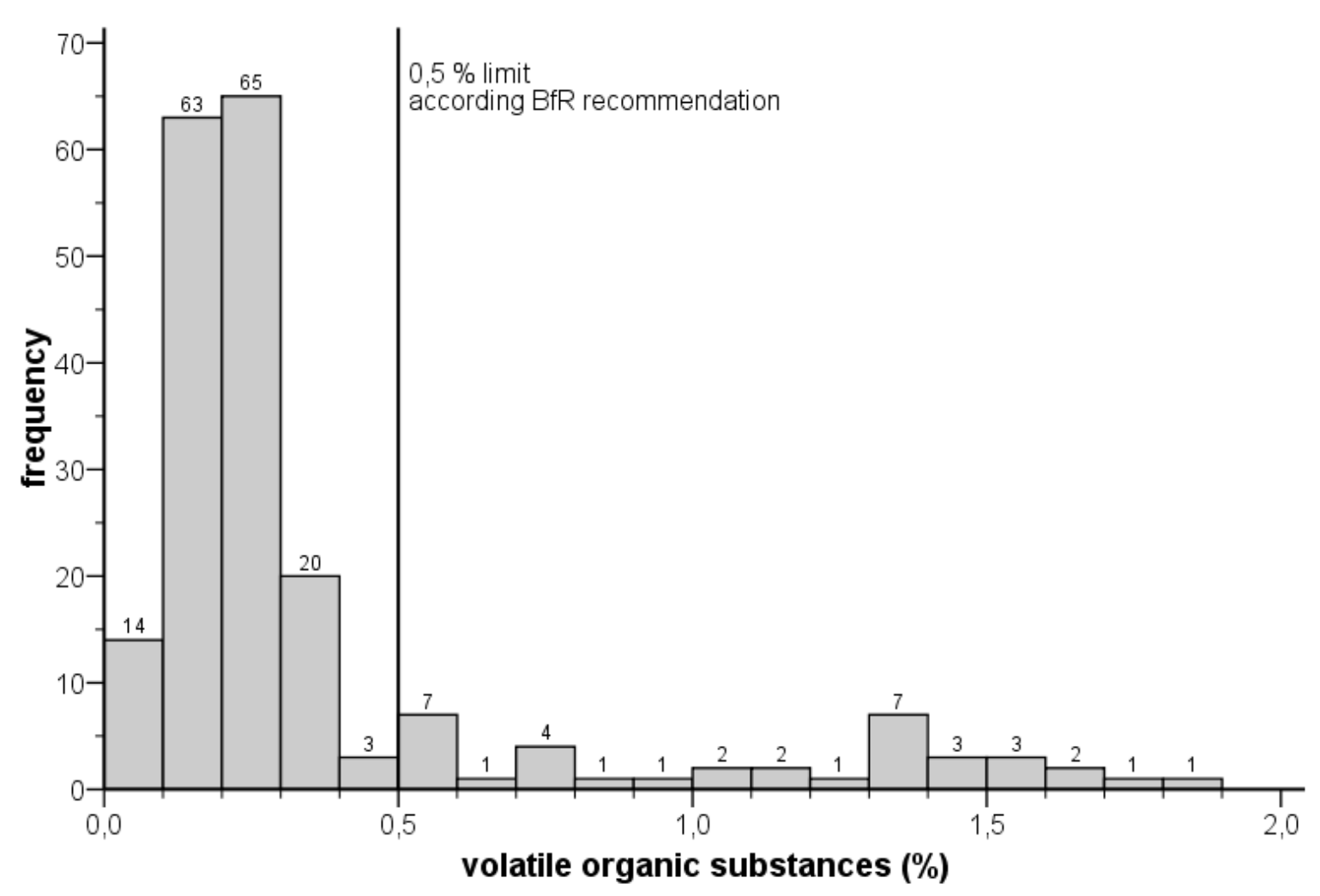

Figure 6. Volatile organic compounds in \% in silicone elastomers for food contact. Data of 201 samples from the German market, analyzed from the official food control authority of Saxony in the years $2004-2009$. In total $18 \%$ of the samples exceeded the limit of $0.5 \%$ as defined in BfR recommendation XV. $68 \%$ contained only $0.3 \%$ or less volatile organic compounds. 